\title{
SCHELLING E STEINER: DA ESSÊNCIA DA LIBERDADE HUMANA AO INDIVIDUALISMO ÉTICO
}

\author{
Jonas Bach Junior* \\ Tania Stoltz ${ }^{* *}$ \\ Marcelo da Veiga ${ }^{* * *}$
}

\begin{abstract}
RESUMO
Este artigo apresenta o conceito de liberdade em Schelling e suas influências na concepção de individualismo ético em Steiner. Schelling explorou nos princípios primordiais da concepção do si-mesmo a essência da liberdade humana. Steiner partiu deste ponto, mas considerou a razão como insuficiente para acessar seguramente o si-mesmo. Para Steiner, a qualidade da consciência que apreende o real do si-mesmo é o pensar intuitivo, que pressupõe um processo de observação fenomenológica da consciência. Este é o ponto de partida do seu individualismo ético, que tornou-se o referencial evolutivo de sua concepção de educação, a Pedagogia Waldorf.
\end{abstract}

Palavras-chave: Liberdade. Individualismo ético. Pedagogia Waldorf.

\begin{abstract}
This paper introduces the concept of freedom in Schelling and its influence on the conception of ethical individualism in Steiner. Schelling explored the essence of human freedom in the overriding principle of the conception of the self. Steiner departed this point, but considered the
\end{abstract}

\footnotetext{
* Doutorado em Educação na UFPR, com bolsa sanduíche do programa Capes/DAAD com estágio na Alanus Hochschule (Alemanha).E-mail: jonasbachjr@yahoo.com.br

** Doutora em Educação pela PUC-SP. Professora Associado II da UFPR. E-mail: tstoltz@, ufpr.br

*** Mestre em Educação pela Pontifícia Universidade Católica do Paraná. Professor dos cursos de Ciências Contábeis e Economia da Pontifícia Universidade Católica do Paraná. Professor do curso de especialização em Gestão Tributária da PUC-PR. E-mail: mdv@ alanus.edu
} 
reason as insufficient to access securely the self. For Steiner, the quality of consciousness that perceives the real self is intuitive thinking, which presupposes a process of phenomenological observation of consciousness. This is the starting point of his ethical individualism, which became the evolving reference of his conception of Waldorf education.

Keywords: Freedom. Ethical individualism. Waldorf Education.

Rudolf Steiner (1861-1925) teve diversas influências para a composição de sua principal obra A Filosofia da Liberdade (1894), como Fichte, Goethe, Hegel, Schelling e Schiller. As reflexões de Schelling na obra A Essência da Liberdade Humana serviram de base ao conceito de individualismo ético steineriano. A individualização - o processo de separação - não escapa à possibilidade do erro, da ilusão ou da inversão dos princípios. O individualismo ético é um processo permanente de formação humana no sentido de, ao mesmo tempo em que se particulariza, manter-se vinculado ao universal. Neste artigo apresenta-se inicialmente a ideia de liberdade em Schelling e sua contribuição para a ideia de liberdade em Steiner. A asserção direta sobre a não essencialidade do mal na obra steineriana, sem as devidas reflexões que culminam em sua conclusão, deixa o entendimento à deriva. Para uma leitura despreparada, parece que o autor simplesmente postula algo, pois não indica a procedência, nem exibe o processo que o conduziu até o seu ponto de partida. A identidade do si-mesmo, como princípio arquetípico da cisão primordial em relação ao fundamento do mundo, é um enigma que requer uma transcendência da subjetivade para sua revelação.

\section{A liberdade arquetípica em Schelling}

Os princípios da regularidade cósmica e terrena são intrínsecos à essência e devir humanos. Na obra de Schelling operam como suporte conceitual para o embasamento coeso e consistente do si-mesmo. A modernidade gira em torno das noções de autonomia e do prefixo "auto", porém - juntamente com o si-mesmo - portam uma insuficiência em seus conceitos, mantendo a questão da liberdade ora em seu conceito formal, ora no abuso do arbítrio, redundando em lugares comuns ou na indignação 
da razão. Surge impreterivelmente a necessidade de um entendimento sobrecomum dentro de um caminho que pretende suplantar a insuficiência conceitual. Liberdade é então questão de desvendar o princípio de ser do homem, revelar o significado e o sentido do fundamento do si-mesmo. Mas chegar a eles pressupõe profundidade e pureza no sentido, fora da esfera ordinária. Assim, a própria linguagem torna-se problemática, porque as palavras têm importância na medida em que apontam na direção dos pensamentos concebidos e não no teor da rigorosidade semântica. Para tanto, as primeiras etapas iniciam aparando as arestas de representações imperfeitas e alertando a nulidade de representações vazias, que são barreiras para se chegar à meta do entendimento vivo. Nas fases intermediárias requerem o discernimento entre o ser e não-ser do homem, o eterno e o devir, o lugar da unidade e da igualdade no homem como fenômeno com origem divina e cósmica (totalidade).

Na ideia originária de homem está a cisão do fundamento na sua contraposição que é a existência. Esse discernimento vem amparar a compreensão da individualidade em Steiner, pois lida diretamente com o enigma da identidade. Os pensamentos de Schelling vasculham pela essência da liberdade humana e para dirimir o cerne do ser humano - como desvelamento dos mistérios do "eu sou" - separa o si-mesmo que na sua diferença permanece em unidade no fundamento, do si-mesmo com caráter periférico que não permite a sua própria manifestação. Este, quanto mais para si, mais é egocêntrico. Aquele, quanto mais singular, mais é perfeito. A asserção "eu sou" é portadora sempre de uma dupla possibilidade de identificação, delineando uma unidade criadora (SCHELLING, 1991, p. 28-29), ou uma unidade uniforme na igualdade. A última tem conotação comum e genérica. A primeira denota seu conceito originário para além do entendimento comum. Então, o si-mesmo, em sua particularidade, ou em sua afirmação pela diferença, é verdadeiro enquanto identificado com a revelação de si próprio (em seu próprio centro). Sua unidade não é igualdade, é identidade via sua especificidade que está em relação com a revelação da totalidade. Por outro lado, o si-mesmo que se afasta do seu centro perde o parâmetro verídico e, uma vez que se projeta na periferia, identificase com a inversão da regularidade fundamental da vida. Sua unidade é uniforme pelo princípio da igualdade: na aparência pode ser diferente, mas na essência é sempre o mesmo nada - a uniformidade está no vazio. 
A dissociação originária entre fundamento e existência incita a nostalgia perene pelo centro, porque o homem quer vir a ser o que é (SCHELLING, 1991, p. 40). Mas a liberdade é um problema porque ela nasceu da cisão e assim é uma possibilidade para o bem e para o mal. Recuperar o elo das forças não é um imperativo, mas um ato livre. O enigma do destino humano é refazer o elo primordial no seu devir em relação ao seu centro. Porém, o si-mesmo possui um princípio obscuro que burla o discernimento entre o central e o periférico. O segredo da sina humana é a sua revelação. Aqui está inserido um conceito radical da essência humana porque busca conceber do que se trata o fundamento primordial do homem. O caminho para a consciência desta concepção é a revelação, que pressupõe a tensão dos opostos para se tornar fenômeno. "O fundamento é só vontade de revelação, para isto, proclama o ser próprio e a contraposição" (SCHELLING, 1991, p. 53). Sem o si-mesmo periférico não há descoberta do central. A obscuridade do si-mesmo é sua condição primeira, mas não necessariamente última. A nostalgia é o movimento arquetípico provocado pelo anseio do si-mesmo em autorreconhecer-se, é uma intenção retroativa que provoca nova dissociação de forças para abdicar da obscuridade. Sem transcender a obscuridade, o princípio do simesmo permanece indistinto, causa seu movimento centrífugo e apega-se à aparência de si. Além disso, inverte a regularidade dos princípios: está dissociado para ser para si. Na centripetação nostálgica, há o respeito à regularidade, a cisão está voltada para o todo e para a vida, e aparece a unidade intacta. "Surge, então, pela primeira vez, o individual, passível de ser concebido não através de representações exteriores, mas mediante uma verdadeira formação interna [Ein-bildung]" (SCHELLING, 1991, p. 42). O sentido genuíno de transformação está conectado ao teor verídico do elemento interior, que se torna entendimento mediante a unidade com a luz. Então, a formação interna é possível através do fundamento em sua direção centrípeta e da existência quando esclarece o fundo obscuro. Entretanto, pertence à inexorabilidade da cisão a indefinição prévia do seu direcionamento. $\mathrm{O}$ ser humano está predestinado a dissociar-se, num ato que se subdivide em duas trilhas: para a unidade originária onde a formação interna adquiriu propriedade de transformação primordial e o ser é mais perfeito quanto mais específico; ou para a unidade pautada pela igualdade, 
onde a transformação atende ao que é para si e falsifica, assim, seu processo de formação. Em ambas, o homem é portador de vontade própria, o que lhe confere o poder de destinar as coisas e a si. Porém, na falsificação a vontade própria está, ou identificada com os desejos e cobiças centrífugos, o eu periférico é fragmento e tateia à deriva no tempo porque seu querer é cego, ou está submetida à universalidade do entendimento.

Mas se através de uma transmutação e cisão progressivas das forças, o ponto mais interior e profundo da obscuridade originária se aclara na luz de um ser, então a vontade desse ser, em sendo individual, é uma vontade particular em si e, enquanto centro de todas as outras vontades particulares, é também una com a vontade primordial ou entendimento, de tal maneira que de ambas surge uma totalidade própria (SCHELLING, 1991, p. 43).

A principal divergência de Steiner está na adequação da vontade própria à razão universal. Para ele, o ato pensante é criador a partir de si mesmo. Nesta incondicionalidade, ele não depende de leis racionais.

Se a vida interna é declarada como vida divina, então parece ser uma inconsequência deter-se numa parte da vida interna. Schelling não cometeu esta inconsequência. No momento em que ele declara que explicar a natureza é criar a natureza, ele dá uma direção a toda sua concepção de vida. Se a contemplação pensante da natureza é uma repetição de sua criação, então o caráter fundamental desta criação deve também corresponder à ação humana; deve ser um ato de liberdade e não o de uma necessidade geométrica. Não podemos, no entanto, conhecer a criação livre por meio das leis da razão; ela tem de revelar-se por outro meio (STEINER, 1955, p. 230) ${ }^{1}$.

1 [Wird das Innenleben als das Göttliche erklärt, dann erscheint es inkonsequent, bei einem Teil dieses Innenlebens stehen zu bleiben. Schelling hat diese Inkonsequenz nicht begangen. In dem Augenblicke, in dem er sagte: die Natur erklären heiße die Natur schaffen, hat er seiner ganzen Lebensanschauung die Richtung gegeben. Ist das denkende Betrachten der Natur eine Wiederholung ihres Schaffens, so muß auch der Grundcharakter dieses Schaffens dem des menschlichen Tuns entsprechen: er muß ein Akt der Freiheit, nicht ein solcher geometrischer Notwendigkeit sein. Ein freies Schaffen können wir aber auch nicht durch Gesetze der Vernunft erkennen; es muß sich durch ein anderes Mittel 
Há uma concordância entre o conceito de Steiner sobre individualidade com as etapas reflexivas de Schelling que configuram o si-mesmo. A diferença da liberdade em Steiner é a inclusão em seu suporte do potencial humano para elaborar o mundo ideativo, em vez de apoiálo sobre a razão. Nos termos concordantes, a singularização do homem é a conquista da personalidade - um processo que, para conhecer o centro mais interior, busca a cisão mais elevada. "Dentre todas as criaturas visíveis, é somente no homem que o centro mais profundo alcança a luz" (SCHELLING, 1991, p. 43). Este processo não espapa da possibilidade do mal, compreendido como inversão da regularidade intrínseca. $\mathrm{O}$ primeiro momento do si-mesmo é ser portador do princípio obscuro, a conquista do princípio luminoso é superação, gera a concomitância de ambos, não desfaz o primeiro. Anular o princípio obscuro seria o absurdo de destituir-se do centro (fusão total no fundamento e perda da existência). A simultaneidade é a regularidade intrínseca. Ser só no fundamento seria "o sono do bem", a morte eterna. Estabilizar na obscuridade é permanecer fechado no centro, a vida perde o seu sentido porque o homem é guiado pelo seu não-ser. "Na medida em que a alma é a identidade viva de ambos os princípios, ela é espírito" (SCHELLING, 1991, p. 44). Entretanto, a simultaneidade, se por um lado é domínio de forças opostas, por outro, é instabilidade, porque o homem é capaz de separar os princípios (possibilidade do mal). Separação significa inversão, a regularidade intrínseca pressupõe concomitância. A espiritualidade humana é o desenvolvimento em busca desse domínio em manter a simultaneidade. "Pelo fato, porém, de possuir espírito (já que esse comanda a luz e as trevas), o si-mesmo, não sendo o espírito do amor eterno, pode separar-se da luz" (SCHELLING, 1991, p. 45). Separado, ele inverte: quereternizaro efêmero(estadodecriatura) ou atribuirefemeridadeao eterno.

Cabe enfatizar que para Schelling (1991, p. 81) os opostos bem e mal não estão em posição dicotômica, como estabelece o dualismo ao estruturar um sistema com duas essências. $O$ bem é a identidade verídica e incondicionada com a essência. "O mal, contudo, não é uma essência, mas uma não-essência [Unwesen], desprovida de realidade em si, guardando-a apenas na contraposição". Na ideia de liberdade steineriana, por outro

offenbaren] (STEINER, 1955, p. 230) (Tradução do autor). 
lado, um fenômeno predicado de mal é relativizado pela superioridade de um outro ponto de vista. Não fosse a manifestação da contraposição, a profundidade sutil da compreensão do bem não se evidenciaria. "Ademais, o mal não é verdadeiramente um mal; apenas sentimos um grau menor do bem como mal. O mal é ausência do bem e nada real por si próprio" (STEINER, 2000, p. 141).

O si-mesmo nunca se estabelece em situação continuamente perfeita porque o devir não está sob seu poder. Para dominá-lo, o si-mesmo precisa integrar-se a ele e superá-lo. Então, para enfatizar seu teor vivo, o si-mesmo tem que ativar-se na medida do devir, trazer à tona a vontade do fundamento que desperta para cada instante. Esta questão serviu de base para o individualismo ético steineriano que, inspirado por um lado pelo conceito moral intuído ante a percepção, por outro, é altruísmo na vontade (na transformação da percepção). Este ato ainda é incompleto, pois para Schelling (1991, p. 72), o bem é quando a vontade do homem inclui "o simesmo ativado juntamente com o amor". O bem requer reequilíbrio duplo, ou seja, focalização no central e ampliação ao periférico. $\mathrm{O}$ individualismo ético assumiu essa dupla tarefa, de ativar o si-mesmo como ato congruente ao conceito de ser do homem e de conferir seu conteúdo à vontade própria. Para Steiner (2000, p. 158), "bem é o que o homem quer quando desenvolve a plena natureza humana".

O antropomorfismo de Schelling é radical e consistente. Sua complexidade domina os aspectos paradoxais do fenômeno da vida ao contemporizar a tautocronia entre bem e mal, abordando os aspectos racionais e irracionais do existir. Entretanto, nele o princípio ideal é uma repetição do fundamento da natureza. Steiner (2000, p. 39) vê no princípio ideal um poder criativo acima da natureza ${ }^{2}$. Porém, ambos (SCHELLING, 1991, p. 67; STEINER, 2000, p. 141) sintonizam ao tomar este princípio como base da consciência moral, além da escolha entre bem e mal, mas como decisão superior, num nível acima da validade genérica.

Como Schelling (1991, p. 34) afirma, a liberdade como faculdade para o bem e para o mal é de grande dificuldade para esclarecimento e

2 Sijmons (2008, p. 2) destaca como diferencial entre Schelling e Steiner a abordagem de ambos na relação entre o mundo das ideias puro e o mundo dos sentidos. 
compreensão. O teor de sua obra tem aqui seu ponto forte. $\mathrm{O}$ outro âmbito desafiador é a conciliação entre a vontade particular e a ordem inerente à totalidade, e este foi todo o esforço de Steiner. Sua Filosofia da Liberdade não é outra coisa senão um método para a formação interna [Ein-bildung] que indica o processo para tal conciliação. Schelling deixa a pista: dentro do princípio ideal (do conceito radical de ser do homem) a vontade nunca acontece para o mal. A busca steineriana é por um meio eficaz de se chegar ao princípio ideal.

A segurança de Steiner para afirmar que a vontade concebida intuitivamente através do mundo ideativo está isenta de um teor imoral baseia-se no princípio de identidade absoluta, onde o mal nunca esteve, nem vai estar. $\mathrm{O}$ conceito de individualidade steineriano comporta a identificação do indivíduo com o conceito de ser do homem. Qualquer vontade gerada fora desse elemento essencial, pelo não-ser, é uma vontade que não pertence ao mundo das ideias, portanto, não pertence à humanidade do homem. O elo que realiza a integralidade das forças cindidas no indivíduo não é uma exigência. Mesmo no estado dissociado, no estado do não-ser, o reestabelecimento do estado associado é um ato livre, no sentido de que não há determinação fora do indivíduo, a não ser nele mesmo, que efetiva o laço. Como criatura, no estado temporal, cada instante é uma situação (percepção) desagregadora. O devir não permite uma estabilidade da absoluta unidade. A condição sensorial da existência é a contraposição necessária para a revelação do fundamento. É por intermédio do não-ser, confrontado ao ser, que a força espiritual humana emerge como domínio sobre as forças antagônicas. A individualidade humana é capaz de manifestar essa terceira força. A possibilidade do mal, ou a gama de ilusões no qual o homem se enreda, é grande. Por dois motivos: porque é impossível permanecer no centro e a tentação de sair dele é tão grande quanto a necessidade de ir em direção a ele; porque no estado invertido, o espírito desagregado usa a "aparência do ser verdadeiro" e conduz o homem por intermédio da "miragem das representações" ao erro (SCHELLING, 1991, p. 64). O indivíduo, ao afirmar-se em sua criatura, nega a si próprio porque insiste em cindir seu princípio constitutivo indiviso. Se essa insistência prossegue e intensifica-se, desdobra-se então na doença, ou até na morte. Esse estado é um individualismo fora da ordem intrínseca do todo da vida. 
Schelling explora a liberdade humana nos primórdios originários da humanidade. Seus parâmetros longínquos são impalpáveis para as representações corriqueiras do cotidiano. A apresentação sucinta de suas ideias neste artigo visa demonstrar os elementos cruciais que estruturam a ideia de liberdade steineriana. Por meio das assserções de Schelling, compreende-se a vida em pensamentos como a vida no fundamento cósmico, ou a vida no divino. Steiner, então, procura demonstrar o pensamento intuitivo como a capacidade humana de concatenar a luz do mundo ideativo ao princípio velado do si-mesmo e da vontade própria. Assim, a liberdade humana é resgatada no eterno começo, no aqui (percepção) e agora (pensar imediatamente vivenciado) do indivíduo. Ela não se torna alvo de debate teológico especializado ou objeto para análise crítica ou teórica. Ela aponta o caminho do individualismo ético na prática da vida palpável como processo de conquista de segurança interior.

\section{Individualismo ético}

Para Steiner, a razão é insuficiente para acessar seguramente o simesmo. A qualidade da consciência que apreende o real do si-mesmo é denominada por ele de "pensar intuitivo", que pressupõe um processo de observação fenomenológica da consciência. A intuição consciente é uma observação realizada pelo eu que acompanha o pensamento da sua gênese ao seu resultado completo e pronto. É uma atividade integralmente inserida na e pela consciência. Como fase inicial de um salto da consciência - a nova dimensão é o pleno domínio de si mesmo por intenção própria - o pensar intuitivo inaugura no indivíduo o começo da superação da subjetividade e o gradual reconhecimento da individualidade autêntica. A inserção do método intuitivo na consciência natural é um paulatino transformador da vida cotidiana. Ao buscar no ato cognitivo o produtor que engendra o objeto da consciência - a ideia ativa - transfere-a ao ato volitivo, completando o processo. O conteúdo da ideia passa para o mundo sensorial (STEINER, 1980, p. 145).

O método de aquisição do pensar intuitivo é heurístico. Cabe a quem empreende, observar a observação para compreender os dois fatores originais do ato cognitivo: percepção e pensar. Quando a observação 
incorre sobre o último, na consciência do pensar coincidem o pensante e o pensado. Este procedimento é viabilizado pelo poder intencional da consciência. $\mathrm{O}$ conteúdo pensado é a própria atividade que lhe gerou, ele determina a consciência, mas não estabelece coação sobre ela, pois é a consciência que determina o conteúdo que será pensado. Não há neste ato mental qualquer conjunto de operações intermediárias, não há estágios dedutíveis, demonstráveis ou raciocináveis. A apreensão não é discursiva, pelo contrário, é imediata.

O pensar vivenciado está longe do racionalismo. Este é um modo esquemático de aplicar a faculdade da razão como única forma de aproximação ao real das coisas. Neste sentido, o pensar vivenciado não prescreve formas fixas de sua manifestação e abre à consciência do sujeito a observação do seu próprio processo que configura as manifestações em formas fixas. O pensar que experiencia a si é:

[...] uma nova perspectiva no desdobramento do pensamento, diferente do intelecto analítico que incorreu na racionalidade quantificadora. Esta forma de pensar, pelo fato de não se fixar em objetivações, mas despertar para a observação de processos plasmadores subjacentes às mesmas é a intuição consciente que integra o homem de modo individual, como ser acional na dinâmica de uma realidade sempre emergente e em transformação. O pensar intuitivo consciente abre o horizonte para uma nova dimensão da produção filosófica, que ultrapassa a perspectiva da mera interpretação de textos e da destruição crítica de posições alheias e se incorpora à vida do indivíduo como prática meditativa. $\mathrm{O}$ pensamento intuitivo, que brota do silêncio meditativo, é capaz de superar o materialismo e convertê-lo em passo intermediário necessário na busca pela realização da autonomia espiritual plena do ser humano (VEIGA, 1998, p. 91).

A experiência do próprio pensar é uma experiência imaterial, coloca a consciência num nível superior, permitindo ao indivíduo a perspectiva do processo que estrutura sua consciência cotidiana. Não há autoridade externa ou coação nos meandros sutis dessa atividade, nem instância algures a se submeter. Uma vez atingida, torna-se propriedade processual do sujeito que precisa ser reacessada. Ela opera na desconstrução positiva da 
subjetividade, os significados e sentidos das coisas adquiridos previamente na vida perdem sua "naturalidade" impositiva. O pensar intuitivo revela a gênese cognitiva atuante da individualidade.

A essencialidade do pensar tem sua fonte no centro universal e na sua expressão multiforme há a pluriformidade infinita. A intuição consciente é a sua condição de não restringir-se a nenhum modo cristalizado, é a liberdade em si porque é ato que sempre se autodetermina. A manifestação é a forma, porém, flexível, adaptada ao objeto percebido.

O método de vivenciar o próprio pensar é um treinamento para aquisição da capacidade de reconhecer a intenção que jaz nos atos de vontade. É uma atividade processual de transparência e honestidade da individualidade para consigo mesma. A individualidade não se constitui instantaneamente e passa a ter garantias permanentes de si sobre o devir. $\mathrm{O}$ genuinamente individual requer um contínuo reacesso de si, uma verificação comparadora com as vozes condicionadas da subjetividade, para gerar um discernimento seguro entre o que pertence ao efêmero e o que é propriedade do permanentemente ativo com base em si mesmo (STEINER, 2000, p. 162). O sentido steineriano de evolução é a sucessão de conquistas da individualidade em sua existência, que despoja-se aos poucos dos atributos da espécie. Não há circunstância material externa e objetiva que seja uma condição sine qua non para a realização desta evolução intuitivamente consciente. Ressalvas cabem a uma constituição psicofísica que não permite o fluxo atuante tornar-se fenômeno fisiológico. A individualidade é um curso evolutivo espiritualizado, é um prosseguimento do patamar alcançado no plano biológico. A ideia evolutiva que determinou o organismo intrinsecamente continua sua marcha progressiva, agora consciente de si própria, no pensar que compreende seu atuar e intui o conteúdo desse atuar.

Os métodos aplicados, em geral, para a compreensão do âmbito humano na vida adotam como objetos os fenômenos onde o espírito se revela, mas não o próprio. São um olhar ao espelho e não ao ente que se espelha. O perspectivismo é fruto de diversas orientações do espelho que em cada ponto onde é colocado apresenta uma imagem diferente. Continuar girando o espelho é expor-se à infinidade da diversidade, é um 
jogo aleatório porque o único ponto fixo é o ser que se faz espelhar e que costuma ser esquecido. A individualidade é o verdadeiramente específico de um ser. A singularidade única não se expressa no ocasional (STEINER, 2004, p. 103). A eventualidade é a manifestação inicial do ser. Essa subjetividade necessita ser superada para que a individualidade conquiste a si própria e se expresse nitidamente. É um jogo dinâmico de duas forças, do refletido e do refletor. O último é mais facilmente apreendido, colabora para a inércia do intelecto comum. O primeiro exige esforço, um autoativarse incessante. No momento em que o refletido cessa sua atividade de permanecer consciente de si (pensar intuitivo), predomina o refletor que se passa, aparentemente, como o único existente. A força do refletor não deve ser menosprezada, salienta-se a prisão humana às eventualidades de suas exteriorizações, como diria Deleuze (1996, p. 31), ao buraco negro da sua subjetividade, com suas paixões e redundâncias.

O individualismo ético é o exercício de uma liberdade condicionada, atrelada ao dever, que não pode ser confundida com "fazer o que bem entende", no sentido licensioso da palavra. Não é entrega passiva aos impulsos instintivos, nem é atender às intenções de atração ou repulsa da psique em relação ao mundo, tampouco é servir a códigos preestabelecidos por costumes deste ou daquele povo, de uma época ou outra. O dever não é uma referência externa ou um padrão de conduta. A noção de um dever, se teve sua validade em alguma situação específica (local e/ou temporal), não significa necessariamente sua permanência em outras circunstâncias. Qualquer fato, fenômeno ou situação é apenas o ponto de vista de um sujeito, é sua percepção individual. Determinada conduta é considerada um dever (de todos) quando culturalmente foi aceita e tradicionalmente cultivada. $\mathrm{O}$ problema ético da humanidade é a intenção de estabelecer universalmente o mesmo conceito de dever que seja válido para todos, em todas as situações. Porém, o fenômeno, ou fato, fornece somente a percepção, é o objeto percebido do sujeito como conceito cognitivo. $\mathrm{O}$ esforço humano tem sido encontrar um conceito (noção) moral como conceito cognitivo. $\mathrm{O}$ apontamento steineriano abrange o conceito moral como conteúdo ideal, onde a percepção é necessária para a compreensão do objeto, mas não como definidora do dever. O conceito moral "dado pelas coisas e situações tem a sua validade, mas num nível superior ele coincide com a ideia à qual 
chego por intuição" (STEINER, 2000, p. 113). O conceito moral superior é encontrado no processo interno individual de superação da subjetividade inicial de qualquer percepção, pela determinação intuitiva de seu conteúdo. Então, a liberdade em Steiner é a realização de um dever que não se orienta pelo prazer que uma ação proporciona ou não. A análise do dever não é pautada pela facilidade ou dificuldade de sua execução, de sua aceitação ou refuta por esta ou aquela forma cultural de compreender os fatos.

Não há unanimidade entre o certo e o errado. A genealogia da moral de Nietzsche foi um passo na revelação da não naturalidade dos mandamentos morais. Entretanto, na liberdade steineriana o princípio não é a negação de um dever qualquer já adotado, ela inclui as múltiplas formas de dever estabelecidas pelas diversas tradições, permitindo ao indivíduo a abertura de encontrar em si próprio a elucidação para sua questão específica. O problema torna-se a capacitação individual para galgar este ponto evolutivo do potencial humano. Qual é o processo requisitado para tal conquista? Quais os parâmetros de um indivíduo para o seu autorreconhecimento de estar neste nível da captação intuitiva do conceito moral de certo fato, no sentido de fornecer a certeza mínima necessária para o ímpeto de uma ação particular?

O outro lado da certeza é o campo da subjetividade - diversas referências que, se comparadas entre si, relativizam o valor uma das outras sem a definição de algo absolutamente válido. A superação inicial do ponto de vista subjetivo é necessária na medida de avançar além do campo perceptivo próprio, porém, o conhecimento de outras perspectivas aumenta a dúvida, não a resolve. A prisão à própria subjetividade é um modo de limitar-se, é um caminho mais confortável de estabelecer valores uma vez que evita a todo custo a confrontação com outros referenciais. $\mathrm{O}$ apego à subjetividade do social, à norma coletiva, é a maneira mais fácil de ser aceito pelos outros. A aceitação do posicionamento de outras subjetividades é um passo inicial e, por um lado, é perturbardora, uma vez que não estabelece o que é exatamente certo ou errado, mas atenua as certezas subjetivas fechadas em si evidenciando suas idiossincrasias.

$O$ processo de um indivíduo para conquistar o grau evolutivo que requer a liberdade steineriana perpassa a transcendência da subjetividade individual e coletiva, e não a sua afirmação. Qualquer preceito moral que se 
validou como motivo ético é uma noção geral para as situações particulares e tem sua importância no caminho evolutivo de um indivíduo. Ninguém atinge diretamente o nível intuitivo sem passar pelos estágios prévios. Enquanto o indivíduo não for capaz de realizar intuições morais, são os códigos éticos que lhe servem de baliza. Steiner (2000, p. 120) apenas não os declara como universais ou como auge evolucionário humano. As leis da sociedade são leis pensadas por individualidades e corresponder a elas está incluído no individualismo ético. Mas estas mesmas leis não são um conjunto estanque, elas precisam de revisão e reformulação porque são frutos de percepções de acordo com certa época de uma sociedade. É possível a um indivíduo ter "intuições melhores", estar à frente de seu tempo, estar além do grupo social no qual se encontra. Isto não quer dizer que a liberdade - eticamente compreendida - redunda em exclusivismo individual: “[...] o homem não pertence somente a si próprio; ele também pertence à sociedade" (STEINER, 2004, p. 104). O individualismo é a evolução do homem, mas não sem o risco do egoísmo excludente, onde a consideração pelos outros é descartada. O individualismo ético é o processo de uma individualidade na aquisição de direção para a realização da sua lei existencial encaixada na ordem do todo. Essa lei existencial encontra diversas maneiras de manifestação em cada indivíduo. A ideia de liberdade humana é uma só, mas na realidade é uma infinidade de manifestações. Querer basear-se nas manifestações alheias, só como imitação de padrão externo sem a afinidade com o conteúdo moral internamente intuído, pode significar o perder-se em meio ao emaranhado de referências subjetivas díspares entre si. Situação conflitiva esta que se encontra o sujeito em condições pós-modernas, onde o meio social é palco de divulgação aberta de inúmeras noções do que é certo ou errado que não concordam entre si.

$\mathrm{O}$ individualismo ético só reconhece o valor da aparência quando esta sintoniza com a essência, que é o conteúdo moral intuído que surge independentemente da percepção do objeto. Este é o parâmetro de reconhecimento para uma individualidade: o conteúdo moral não espera por comparações com outras manifestações da ideia de liberdade. Ele é imediatamente o motivo e a força motriz de uma ação. A própria ideia intuída é a vontade despertada. O indivíduo eticamente imbuído reconhece o valor de um pensamento pela sua força inerente. Na intuição moral, o 
pensar é um querer, o espírito é no corpo. Não existe separação, a liberdade steineriana é uma conquista da unidade em si próprio. Ela não se faz sem o conhecimento, sem o processo cognitivo, sem o romper com as barreiras da subjetividade, sem o esforço interno, sem a transcendência da sua perspectiva. "'Pontos de vista' como materialismo, realismo, idealismo, espiritualismo, tal qual são desenvolvidos por pessoas de orientação abstrata para elaborar teorias complicadas no mundo físico, a fim de significarem algo inerente às próprias coisas, perdem todo e qualquer interesse para o conhecedor do supra-sensível" (STEINER, 2006, p. 223224). Neste sentido, a liberdade steineriana é a luta interna para superar o idealismo unilateral também. Parte-se dele em direção à realidade concreta. Somente a ideia intuída não faz sentido. É idealismo objetivo porque não se abandona às abstrações, porém assume-se na existência concreta do mundo. A realidade exclusiva do pensar é incompleta, o querer desperto por ele é a sua continuidade. O conteúdo do pensar só alcança a plenitude quando acontece na vida.

Ao mesmo tempo em que é individualismo - porque se funda sobre a ideia intuitiva por um indivíduo específico - este somente é ético quando o móbil da ação é o amor por ela mesma. Então, individualismo ético não é amor do indivíduo por ele mesmo (egoísmo, subjetividade), é amor pela ideia da ação (STEINER, 1980, p. 149-150). Qualquer ação movida por egoísmo tem alguma intenção de proveito por detrás. Se o proveito não é possível, a ação não se realizaria. A atitude ética livre não exclui algum benefício que o indivíduo possa ter com ela, mas não está presa unicamente aos benefícios próprios como meta. O individual é a intuição, o ético é o seu altruísmo na realização. $O$ indivíduo se afirma em si pela ideia e renuncia a si na ação. A ação individual onde o indivíduo requisita algum retorno para si não está pautada na ação livre propriamente dita, desviou-se para os interesses do indivíduo e possui um cunho egoísta, uma coação do interesse próprio. Para o idealismo não ser absoluto, o individualismo ético torna a ação absoluta, no amor que reside nela mesma; ele é o fundamento do idealismo objetivo. O amor, neste sentido, é a força devotada à concretização da ação que não está coagida por benefícios individuais, não tem por condição a espera de algum proveito. É doação absoluta ao ato em si. O conteúdo moral intuído e manifesto é propriedade exclusivamente individual, mas sua realização é para o mundo, é propriedade geral. 
O diferencial da ação no individualismo ético é que o seu altruísmo não possui necessariamente a conotação religiosa do termo. Define simplesmente o aspecto abnegado do ato, porém mantém a fonte inspiradora da atitude fora dos princípios religiosos. Ou seja, agir conforme um mandamento altruísta apenas acatando-o como autoridade externa não é uma ação livre. O indivíduo submete-se, realiza algo que é valorizado pelo grupo social ao qual pertence. Implicitamente pode até esperar o proveito do reconhecimento social para si, ocultando um egoísmo no ato denominado de altruísta. O altruísmo da ação do individualismo ético refere-se ao fenômeno de renúncia da subjetividade e da organização psicofísica humana; elas cedem suas predisposições para a manifestação direta da ideia.

O individualismo ético é o princípio do sujeito abnegado. A individualidade é mais autêntica quanto mais se autoafirma e se autorrevela pela ideia intuída e quanto mais renuncia a si própria na ação ideativa. As ações onde não há renúncia não pertencem à individualidade genuína, porém a algo que em certo grau é relativo ao comum. A renúncia de si próprio na ação exime o indivíduo do próprio egoísmo, no sentido da manutenção de seu cunho ético. A questão, para não cair na ingenuidade fácil, é manter a concepção intuitiva da ação conectada também aos seus efeitos sobre os outros, para não se tornar alvo do interesse alheio. Em outras palavras, há o risco do altruísmo de um indivíduo trabalhar em prol do benefício egoísta de outros.

É o próprio pensamento intuitivo que opera como avaliador das consequências da ação da vontade no mundo. O conteúdo ideal determina o que deve ser feito, mas toda ação realizada transforma-se em percepção. $\mathrm{O}$ fruto da ideia inserida no mundo é um conteúdo percebido, que num círculo retroativo, gera um novo conceito que pode vir a ser a ação reformulada.

Não existe individualismo ético se o indivíduo não desenvolveu em si e por si próprio o conceito de si-mesmo. Sem o conceito de ser livre, as ações requisitam os princípios por uma autoridade externa. $\mathrm{O}$ pensar intuitivo é a capacidade de configurar pensamentos que emanam do conceito de si mesmo como espírito livre, que fornece a representação mental da lei que jaz na existência individual. O indivíduo somente tem 
o direito de desconsiderar o que os outros fariam em certa situação se ele mesmo se autolegisla. Para o espírito livre, o que vive em seu coração está amalgamado com os impulsos para a realização da intuição moral.

A ideia do individualismo ético não diz que o homem é livre. Ela aponta apenas para uma possível liberdade a ser conquistada a partir da transformação da consciência. Assim como o homem, inicialmente preso à dicotomia entre sujeito e objeto, pode elevar-se à compreensão dinâmica da realidade, ele pode superar também a dicotomia entre dever e paixão. É preciso pensar o homem capaz de evoluir também mentalmente, e não apenas num sentido biológico (VEIGA, 2001, p. 93).

O direito ao direito de espírito livre é querer para si o dever do dever. O receio que existe na liberdade individual é o desmantelamento da ordem social se cada um faz o que quer. $\mathrm{O}$ individualismo negativo fundamentado sobre o egoísmo e o hedonismo é somente o dever do direito; o preceito é uma subversão para a harmonia do todo social, pois as partes rompem com a solidariedade da coesão e requisitam que o todo (o social) sirva-lhes, atenda aos interesses exclusivamente individuais fechados em si e excludentes (sem consideração das consequências sobre os outros). O individualismo exclusivista e excludente é o dever do direito, a exigência da licenciosidade.

$\mathrm{O}$ individualismo positivo fundamentado no eu compromissado com o devir existencial próprio e alheio é o direito do dever; o preceito é a condição para a harmonia do todo, pois as partes estabelecem laços solidários a partir da coesão interna. É a coesão individual somada em diversas individualidades que forma a coesão do todo. $\mathrm{O}$ individualismo ético é o direito do dever, a licença para realizar a exigência da lei existencial, é querer o dever particular.

Steiner problematiza a questão definindo a ação verdadeiramente individual não como aquela que segue seus impulsos ou que é serva de suas cobiças. Ação individual é aquela orientada pelas ideias intuídas no conceito de espírito livre do indivíduo. Este conceito não é dado, os moldes culturais não o possuem e o comunicam aos indivíduos. $\mathrm{O}$ 
individualismo ético pressupõe a elaboração ativa de um conjunto de ideias para a configuração do conceito da própria personalidade individual. As metas do desenvolvimento ontológico situam-se na lei inata de ser e vir-a-ser (evoluir). A questão é que a genuína individualidade transcende a racionalidade. Ela não cabe no escrutínio racional, ela está em um patamar mais profundo, é um nível mais intenso de existir.

A humanidade tem exercitado seu poder reflexivo para dirimir as questões éticas. Quando o pensar racionalizado se amplia, ele chega ao patamar da ambivalência. Por um lado, rompe com os limites de uma racionalidade unilateral que se restringia a ver apenas uma face da realidade. Por outro lado, ao revelar que a "luz e a sombra" coexistem em cada fenômeno e que toda ação tem desdobramentos em ambas as direções, não deixa um parâmetro seguro para a tomada de resolução. $\mathrm{O}$ individualismo só é ético se o pensar que o guia for intuitivo. E este pensar não se pauta por princípios externos, não analisa se seu intuito é bom ou mau - o que sempre é relativo e ambíguo -, não é moldado ao que todos fazem, não obedece aos instintos, nem serve aos mandamentos morais. Como analisa Bauman (1997, p. 28), na época atual predomina um pluralismo de normas, não há a norma a ser obedecida ou transgredida. O que há é um conjunto de normas distintas sob o discurso de diferentes autoridades.

No fim, não confiamos em nenhuma autoridade, pelo menos, não confiamos em nenhuma plenamente, e em nenhuma por longo tempo: não podemos deixar de suspeitar de qualquer pretensão de infalibilidade. Este é o aspecto prático mais agudo e importante do que justamente se descreve como a crise moral pós-moderna" (BAUMAN, 1997, p. 28).

O ambiente social é multirreferencial, não oferece segurança absoluta para a tomada de decisão. $\mathrm{O}$ eu moral corre o risco de recuar ante sua possibilidade de se fazer individualmente ético, para fugir da solidão, para não vislumbrar sua impotência. Acaba, assim, cedendo a novas formas de autoridade ou conformando-se ao padrão que é coletivamente aceito.

A crise de identidade permeia a vida humana na contemporaneidade. O individualismo ético é a postura de uma identidade em contínua 
construção e formação. A gnosiologia de Steiner destaca a mobilidade e a profundidade possíveis de serem alcançadas pelo conhecimento. Há sempre espaço para uma perspectiva superior, que pressupõe mais intensidade da atividade do indivíduo.

Portanto, descobrimos o eu antes de tudo na consciência do pontencial não-realizado de qualquer experiência. Se nós perguntarmos o que isso significa, Steiner o tem descrito como um tipo de "buraco" psíquico ou um espaço negativo. O que quer que façamos com ele inicialmente é algo obviamente posterior a Hume ou também é uma concepção de identidade pós-moderna. O eu é essencialmente o que as coisas não são. Certamente, podemos encontrar uma imagem do nosso eu no registro das experiências passadas que nos transformaram no que somos agora, mas nossa verdadeira identidade não é definida por essas experiências; se fosse assim, não seríamos pessoas, mas armários cheios. Em vez disso, temos uma identidade contínua, uma individualidade, exatamente porque podemos continuar absorvendo mais experiências de forma unificada (WELBURN, 2005, p. 143).

A situação cultural nos moldes pós-modernos precipita uma condição humana para a qual a humanidade não está previamente preparada. O individualismo possui seu caráter duplo por conta disso. A superação dos aspectos negativos e antissociais do individualismo tornou-se uma meta da educação para a evolução da humanidade. Steiner, quando fundou a Pedagogia Waldorf (em 1919), estabeleceu o exercício do individualismo ético como a base da autoeducação dos professores. Como condição reflexa das estruturas sociais, ou da dinâmica social contemporânea, o individualismo é uma ameaça quando deriva para um cunho exclusivista, é fechado em si, voltado só para o atendimento das necessidades corporais (vitais e de prazer), ou para a cumplicidade consigo próprio (conforto, sensações agradáveis, sentimentos suaves, decisão orientada sempre pelos caminhos mais fáceis, comodismo nos pensamentos e passividade na ação). Predomina o senso estético supérfluo em detrimento do senso ético. $\mathrm{O}$ individualismo não é um mau em si, sua inclinação ao individualismo excludente é que o deturpa. Individualismo é o fenômeno, é o substantivo, é o conceito. Ético é a sua qualidade, sua profundidade, sua essencialidade. $\mathrm{O}$ individualismo exclusivista é superficial, vazio, é só a aparência falsa. 


\section{Conclusão}

Schelling, para dar suporte à insuficiência do conceito de si-mesmo, busca apreender o enigma da liberdade humana no elemento primordial, porém ainda pautado na razão. Steiner transpôs o princípio originário da cisão do fundamento para o desafio do aqui e agora da existência. Isto pressupõe o desenvolvimento de uma qualidade intuitiva da consciência, que faz parte de um processo evolutivo individual. A liberdade de Steiner remete à sua aplicação individual, mas tem sua fonte no manancial das ideias, que é única (universal), mas multiforme na sua manifestação. Neste sentido, a teoria de Steiner é uma metanarrativa que não trilhou pelos erros ou ilusões da modernidade que pretendia totalizar a razão. A manifestação da ideia moral da liberdade é plural e não padronizada. Os estilos de vida heterogêneos da pós-modernidade não ferem o princípio steineriano, nunca houve pretensão alguma de fazer uma filosofia que fosse a estabelecedora do código para os indivíduos. O significado de filosofia para a modernidade em Steiner não concorda com o conceito dominante neste campo acadêmico. Sua filosofia é fundada em princípio próprio, alternativo ao centro formalizado e tradicional; não é um grande esquema interpretativo que fornece "o modo correto" de se pensar. Pelo contrário, insiste em apontar que ninguém é detentor de um único modo correto de pensar que seja aplicável a todas as situações. É o objeto que requer o modo de observação e, por sua vez, o modo de conceituação. As múltiplas formas de alteridade que são oriundas das diferenças de subjetividade, gênero, sexualidade, raça, classe e de configurações de sensibilidade temporal e local, são resultado da atividade do pensar, que em si é uniforme e emana do centro do fundamento do mundo. $\mathrm{O}$ desenvolvimento da qualidade intuitiva da consciência é questão de autoeducação para alçar sua fonte vivificadora e fundar assim um individualismo que é ético.

\section{Referências}

BAUMAN, Zygmunt. Ética pós-moderna. Tradução João Rezende Costa. São Paulo: Paulus, 1997.

DELEUZE, Gilles. Mil platôs: capitalismo e esquizofrenia. v. 3. Rio de Janeiro: Ed. 34, 1996. 
SCHELLING, Friederich W. J. A essência da liberdade humana: investigações filosóficas sobre a essência da liberdade humana e das questões conexas. Petrópolis, RJ: Vozes, 1991.

SIJMONS, Jaap. Phänomenologie und Idealismus: Struktur und Methode der Philosophie Rudolf Steiners. Basel, Suíça: Schwabe Verlag, 2008.

STEINER, Rudolf. Die Rätsel der Philosophie: in ihrer Geschichte als Umriss dargestellt. Dornach, Suíça: Rudolf Steiner Verlag, 1955. . A obra cientifica de Goethe. São Paulo: Associação Pedagógica Rudolf Steiner, 1980.

- A filosofia da liberdade: fundamentos para uma filosofia moderna: resultados com base na observação pensante, segundo método das ciências naturais. São Paulo: Antroposófica, 2000.

- O método cognitivo de Goethe: linhas básicas para uma gnosiologia da cosmovisão goethiana. São Paulo: Antroposófica, 2004.

- Minha vida: a narrativa autobiográfica do fundador da Antroposofia. São Paulo: Antroposófica, 2006.

VEIGA, Marcelo da. Experiência, pensar e intuição: introdução à fenomenologia estrutural. São Paulo: Cone Sul, 1998.

. Filosofia da liberdade e noociência. In: MIKLÓS, Andreas A. W. (Org.). A dissociação entre homem e natureza: reflexos no desenvolvimento humano. São Paulo: Antroposófica; Botucatu: Associação Brasileira de Agricultura Biodinâmica, 2001.

. Rationalität und Intuition. In: SCHIEREN, Jost (Hrsg.). Rationalität und Intuition in philosophischen und pädagogischen Perspektive. Frankfurt, Deutschland: Peter Lang, 2008.

WELBURN, Andrew J. A filosofia de Rudolf Steiner e a crise do pensamento contemporâneo. São Paulo: Madras, 2005.

Data de registro: $15 / 03 / 2012$

Data de aceite: 19/06/2013 